隣接臓器に進展した腎細胞癌に対する治癒的

\title{
および非治癒的腎摘出術の成績
}

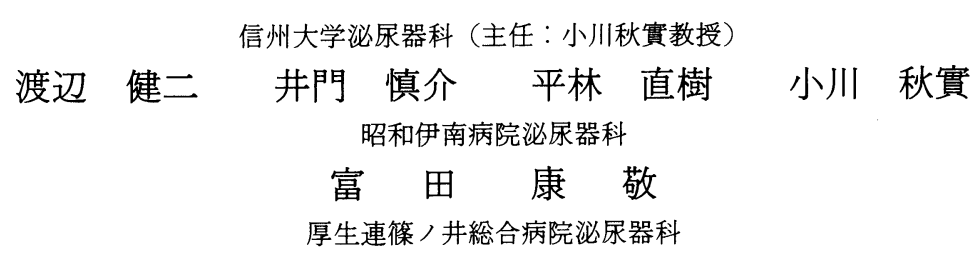

和 食正 久

\section{RESULTS OF CURATIVE OR NON-CURATIVE NEPHRECTOMY FOR RENAL CELL CARCINOMA INVADING ADJACENT ORGANS}

\author{
Kenji Watanabe, Shinsuke Ikado, Naoki Hirabayashi and Akimi Ogawa \\ Department of Urology, Shinshu University School of Medicine \\ (Director: Prof. A. Ogawa) \\ Yasunori Tomita \\ Division of Urology, Showa Inan General Hospital \\ Masahisa Wajiki \\ Division of Urology, Shinonoi General Hospital
}

We reviewed 12 patients who had undergone curative or non-curative nephrectomy for renal cell carcinoma invading adjacent organs (stage T4). 83 patients with renal cell carcinoma confined within the perirenal fascia (T1-T3) who had undergone nephrectomy served as controls. Of the 12 patients with T4 tumor 6 had undergone simultaneous excision of involved adjacent organs (hemicolectomy in 4 , resection of the tail of pancreas in 5 , splenectomy in 2). At operation 6 patients with T4 tumor had distant metastasis, 3 had fixed lymph node metastases, and 4 had tumor extention into the main renal vein or vena cava. Although T4 tumor had distant or fixed lymph node metastasis more frequently than T1-T3 tumors, the incidence of gross tumor thrombus showed no such difference between T3 and T4 tumors. Postoperative follow-up of patients with T4 tumor showed that local recurrence developed within 9 months in 3 of 5 patients who had undergone curative excision, new distant metastasis developed within 6 months in 5 patients, 1 patient died of acute renal failure in the early convalescence, 10 patients died of the disease within 12 months and 1 died of the disease in 31 months. Pathological examination showed that T4 tumors tended to be classified as grade 3 , to extend in an infiltrating fashion and to have a sarcomatoid structure. Patients who had a tumor where these three histological features were dominant died to tumor within 3 months after nephrectomy. These results indicate that curative excision of $\mathrm{T} 4$ renal cell carcinoma is not only difficult, but frequently associated with early local recurrence and new distant metastasis. A more effective adjuvant therapy is required to improve the prognosis of $\mathrm{T} 4$ renal carcinoma.

Key words: renal cell carcinoma, nephrectomy, extended surgery

要旨：隣接藏器に進展した腎細胞癌（T4）12例について病理組織像と腎摘出術後の転帰を調査した。進 展度がそれ以下の腎細胞癌で同時期に腎摘出術を行った89例のらち T病期を確定できた83例を対照と して同様の調査を行った. T4 12例のうち 6 例に隣接臟器合併切除を施行した(結腸半切 4 例, 膵尾部切 除 5 例, 脾摘 2 例). T4症例のうち 6 例に初診時遠隔転移が， 3 例に手術時に固定したリンパ節転移が認 
められ，これらは T1〜T3症例に比し有意に高率であった。 T4症例のうち 4 例に手術時に腎静脈に及ぶ 腫瘍血栓が認められたが, その頻度は $\mathrm{T} 3$ 症例と有意差はなかった。治癒切除できた 5 例中 3 例が術後 9 カ月以内に局所に再発を起こした. T4症例の 5 例では術前に見られなかった新しい遠隔転移が腎摘出後 6 カ月以内に発現した。術後急性腎不全で死亡した 1 例を除く 11 例が術後 3 年以内に癌死し, そのうち 10例は 1 年以内に死亡した。 T4症例のらち術後自宅療養あるいは社会復帰（performans status 2以下） できた期間が 2 力月を越光た症例は 3 例であった。組織学的には $\mathrm{T} 4$ は細胞異型度 $\mathrm{G} 3$, 浸潤様式 $\gamma$, 肉 腫様構築を持つことが多く，これらのすべてを主成分として有した症例は術後 3 カ月以内に癌死した. これらの結果から, T4腎細胞癌は治癒切除が難しく, しかも局所再発と遠隔転移が術後早期に起こりや すいと言光る、T4症例の予後の改善には, より有力な補助療法が必要と思われる.

キーワード：腎腫瘍，腎摘出術，拡大手術

\section{緒言}

隣接藏器へ進展した腎細胞癌に対する腎摘出術の成 績は, 1980年代前半までは Robson 分類に基づいて, 遠 隔転移を有する場合と一括して論じられていた。 1980 年代後半から TNM 分類が行われるようになってか らも, 隣接臓器へ進展した腎細胞癌 (T4) は極めて予 後が悪く, しかも症例数が少ないため, 病理像や転帰 について詳しく論じた報告はほとんどなく, 臟器合併 切除を含む拡大手術あるいは明らかに非治癒切除に終 わる症例の腎摘出術の意義についても不明の点が多 い。われわ机は，過去 12 年間に 1 蔵器遠隔転移例 6 例 を含む T4腎細胞癌12例に対して, 臓器合併切除を含 む拡大手術あるいは非治癒切除に終わる場合でも術後 の補助療法に期待して腎摘出術を施行し，その病理像 と転帰から T4腎細胞癌に対する治癒的拈よび非治癒 的腎摘出術の意義について考察した。

\section{対象と方法}

信州大学泌尿器科において1978年 4 月から1990年 3 月までの 12 年間に, 腎細胞癌 99 例に対し腎摘出術を施 行した。このうち病期 $\mathrm{T} 4$ の腎細胞癌は10例であった。 これに関連病院の 2 例を加え, 腎摘出術を行った T4 腎細胞癌12例について病理組織像と転帰を調查した。 なお，同時期に信州大学泌尿器科で腎摘出術を行った 病期 $\mathrm{T} 3$ 以下の 89 例のらち, $\mathrm{T}$ 病期を確定できた 83 例 について, 対照として同様な調査を行った. 病理所見 と病期は腎癌取扱い規約 ${ }^{1}$ に基づいて分類した。腸腰 筋の中に腎腫瘍と連続する明らかな腫瘍塊を認めた 3 例は，病理組織学的に腫瘍境界が検索されていなくと も T4症例に含めた。

生存率は Kaplan-Meier 法にて算出した。起算日は 手術日とし,転帰は1990年 9 月10日をもって判定した。 有意差検定は Generalized Wilcoxon 検定, 尤度比法, $\chi^{2}$ 検定および Mann-Whitney U 検定を用いた。

\section{結 果}

調査対象症例を表 1 に示す．調査対象95例の経過観 察期間は中央值 1 年 10 力月, 最長 11 年 5 力月で， 7 例 は追跡調査不能であった。

転㷌の判明した 88 例の 5 年生存率は全体で $54 \%$,

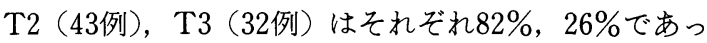
た. T4 (12例) は 1 年生存率 $8 \%, 3$ 年生存率 $0 \%$ で あった。

表 2 に T4症例の病期, 浸潤部位, 臓器合併切除の有 無, 肉眼的な治癒切除の有無, 術後の局所再発の有無, 術後新たな他臓器転移の有無，転帰を示す，明らかな 腫瘍浸潤部位を指で剥離したり，明らかなリンパ節転 移を取残したり，腫瘍をこぼした場合は腫瘍残存に含 めた。 6 例に藏器合併切除を施行した。12例中 7 例が 治癒切除できず，治癒切除と思われた 5 例のうち 3 例 は術後 9 カ月以内に局所再発を起こした。腎摘出術前 に遠隔転移が明らかでなかった 6 例中 4 例に術後遠隔 転移が出現し，腎摘出術前に遠隔転移の認められた 6 例中 2 例に術後新たな他臓器転移が出現した。新たな 遠隔転移の出現は 6 例中 5 例が腎摘出術後 6 力月以内 であった。術後急性腎不全で死亡した 1 例を除く全例 が腎摘出後 3 年以内に癌死し，そのうち 10 例は 1 年以 内に死亡した。剖検所見では，手術時に認められた浸

表 1 対象症例

\begin{tabular}{c|c|c}
\hline & T1-T3 & T4 \\
\hline 症例数 & 81 & 12 \\
男 & 61 & 8 \\
女 & 22 & 4 \\
\hline 年齢(歳) & $33 \sim 83$ & $33 \sim 72$ \\
(平均) & 62 & 56 \\
\hline 患側 右 & 33 & 3 \\
左 & 50 & 9 \\
\hline
\end{tabular}


表 2 T4症例の病期,浸潤組織掞よび転帰

\begin{tabular}{|c|c|c|c|c|c|c|c|c|c|}
\hline \multirow{2}{*}{ 症例 } & \multicolumn{3}{|c|}{ 病 期 } & \multirow{2}{*}{ 浸 潤 組 織 } & \multirow{2}{*}{ 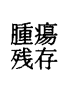 } & \multirow{2}{*}{$\begin{array}{l}\text { 局所 } \\
\text { 再発 }\end{array}$} & \multirow{2}{*}{ 新転移 } & \multirow{2}{*}{ 転起 } & \multirow{2}{*}{ 告存数 } \\
\hline & V & $\mathrm{N}$ & M & & & & & & \\
\hline 1 & $\mathrm{x}$ & $\mathrm{x}$ & 0 & [膵], [結腸 $]$ & - & $+^{*}$ & + +(肺) & 癌死 & 7 \\
\hline 2 & $1 \mathrm{~b}$ & $\mathrm{x}$ & 0 & 肝, 体壁, [結腸] & + & H & ? & 癌死 & 3 \\
\hline 3 & 2 & $\mathrm{x}$ & 1(肺) & [朠], [脾], [結腸 ] & - & ? & ? & 癌死 & 9 \\
\hline 4 & 1a & 3 & 0 & [腪], [脾], [大網] & - & H & + (肺) & 癌死 & 9 \\
\hline 5 & 2 & 2 & 1(肺） & [羘］ & + & $?$ & $?$ & 癌死 & 1 \\
\hline 6 & $1 \mathrm{~b}$ & 2 & 0 & [苹], [結腸］ & + & + & + (肺) & 癌死 & 3 \\
\hline 7 & la & 3 & 1(骨) & 腸腰筋, 結腸間膜 & + & + & + (肺) & 癌死 & 12 \\
\hline 8 & $\mathrm{x}$ & $\mathrm{x}$ & 1(肺) & 肝 & + & $+^{*}$ & $?$ & 腎不全 & 0.5 \\
\hline 9 & 1a & 3 & 0 & 横隔膜 & - & \# & ? & 癌死 & 3 \\
\hline 10 & 1a & $\mathrm{x}$ & 0 & 腸腰筋 & + & $?$ & + (骨) & 癌死 & 31 \\
\hline 11 & $\mathrm{x}$ & $\mathrm{x}$ & 1(肺) & 肝, 腸腰筋, 結腸間膜 & + & \# & $?$ & 癌死 & 12 \\
\hline 12 & 0 & 0 & 1(肺） & 結腸間膜 & - & - & + (脳) & 癌死 & $10 \#$ \\
\hline
\end{tabular}

[ ] =部分切除蔵器, + =腹壁に及ぶ巨大な再発, ${ }^{*}=$ 剖検で局所再発あり, $\#=1990$ 年11月 3 日死亡

表 3 T4症例の組織型および腫瘍径

\begin{tabular}{c|l|c|c|c}
\hline 症例 & \multicolumn{1}{|c|}{ 構築型 } & 異型度 & 浸潤様式 & 腫㾮径 $(\mathrm{cm})$ \\
\hline 1 & 肉腫様 & $\mathrm{G} 2>\mathrm{G} 3$ & $\gamma$ & 13 \\
【2】 & 肉 $>$ 胞 & $\mathrm{G} 3>\mathrm{G} 2$ & $\gamma$ & 17 \\
3 & 肉=胞 & $\mathrm{G} 3>\mathrm{G} 2$ & $\beta$ & 15 \\
4 & 肉=胞=乳 & $\mathrm{G} 3$ & $\beta$ & 15 \\
【5】 & 肉腫様 & $\mathrm{G} 3$ & $\gamma$ & 13 \\
【6】 & 肉腫様 & $\mathrm{G} 3$ & $\gamma$ & 15 \\
7 & 乳頭 & $\mathrm{G} 2$ & $\beta$ & 15 \\
8 & 胞单 & $\mathrm{G} 1>\mathrm{G} 2$ & $\beta$ & 11 \\
【 】 & 肉 $>$ 胞 & $\mathrm{G} 3>\mathrm{G} 2$ & $\gamma$ & 10 \\
10 & 胞=乳 & $\mathrm{G} 2$ & $\alpha$ & 3.5 \\
11 & 乳頭 & $\mathrm{G} 1>\mathrm{G} 2$ & $\beta>\alpha$ & 15 \\
12 & 胞 $>$ 肉 & $\mathrm{G} 2>\mathrm{G} 3$ & $\beta$ & 7.5 \\
\hline
\end{tabular}

潤部位から離れた摘出床に接する臓器表面にも局所再 発が認められた。

表 3 に T4症例の組織学的所見および腫瘍の長径を 示す。腫瘍径は10例 $(83 \%)$ )か長径 $10 \mathrm{~cm}$ 以上であった。 なお，T2症例の $16 \% ， \mathrm{~T} 3$ 症例の $32 \%$ が長径 $10 \mathrm{~cm}$ 以上 であった. 肉腫様構築，G3，浸潤様式 $\gamma$ の全てを主成 分として有していた 4 例（症例 $2 ， 5 ， 6 ， 9$ ）が術 後 3 カ月以内に癌死した。

表 4 に T 病期別の術前遠隔転移と静脈浸潤, 所属リ ンパ節転移の有無を示す。病期が進むと術前遠隔転移 の合併頻度が増加した $(\mathrm{p}<0.01)$ ．静脈内に腫瘍を認 めないもの $(\mathrm{pV} 0)$ と腫瘍からの還流静脈内に浸潤があ るもの (pV1a)を腫痬血栓なし $(\mathrm{V}-)$, 腎静脈内に腫 瘍血栓があるもの (pV1b) と大静脈内に腫瘍を認める
表 4 病期と転移, 静脈浸潤の関係

\begin{tabular}{l|c|l|c|l|l}
\hline & T1 & \multicolumn{1}{c|}{ T2 } & \multicolumn{1}{c|}{ T3 } & \multicolumn{1}{c|}{ T4 } & \multicolumn{1}{c}{ 計 } \\
\hline $\mathrm{M}+(\%)$ & $0 / 1$ & $4 / 46(9)$ & $9 / 36(25)$ & $6 / 12(50)$ & $19 / 95(20)$ \\
$\mathrm{V}+(\%)$ & $0 / 1$ & $6 / 43(14)$ & $11 / 30(37)$ & $4 / 9(44)$ & $21 / 82(26)$ \\
$\mathrm{V} 2$ & & $2 / 43$ & $4 / 30$ & $2 / 9$ & $8 / 82$ \\
$\mathrm{~N}+$ & $0 / 1$ & $0 / 7$ & $3 / 7$ & $5 / 6$ & $8 / 21$ \\
$\mathrm{~N} 3$ & & & $1 / 7$ & $3 / 6$ & \\
\hline
\end{tabular}

$\mathrm{M}+$ は術前遠隔転移有り $\mathrm{V}+$ +腎静脈あるいは大動脈に腫

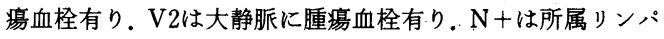
節に転移有り。N3は固定リンバ節転移有り。分母は調查症例 数, 分子は陽性症例数.

静脈浸潤不明13例，リンパ節転移不明74例（リンパ節生検で 転移の見られなかった T34 例はリンパ節転移不明とした。）

もの（pV2）を腫瘍血栓あり（V+）とすると，病期が 進むと腫瘍血栓を有する率が高くなった $(\mathrm{p}<0.01)$. ただし, 腫瘍血栓の頻度は, T3症例と T4症例の間で有 意差は認められなかった。95例のらちリンパ節郭清は 13例（T1 T3 12例， T4 1 例）に行い, 全例組織学的 に陰性であった。術中触診及び視診で転移の疑われる リンパ節は摘出した $(\mathrm{T} 3 ： 7$ 例, $\mathrm{T} 4: 6$ 例)が, T4症 例は触診及び視診で明らかなリンパ節転移を有する率

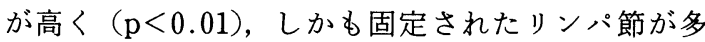
かった。

表 5 に組織学的検索ができた92例の $\mathrm{T}$ 病期と細胞 異型度, 浸潤様式との関係を示し, 表 6 に追跡調査が できた86例の細胞異型度, 浸潤様式別の生存率を示す。 生存率は異型度が高い注ど低く, 浸潤様式が $\alpha, \beta, \gamma$ の順に低かった。 T4症例には異型度 G3を主とするも 
表 5 細胞異型度, 漫潤様式と T病期別の症例数

\begin{tabular}{c|c|r|r|r|c}
\hline & $\mathrm{T} 1$ & $\mathrm{~T} 2$ & $\mathrm{~T} 3$ & $\mathrm{~T} 4$ & 計 \\
\hline 異型度 & & & & & \\
1 & 0 & 13 & 3 & 0 & 16 \\
2 & 0 & 29 & 26 & 4 & 59 \\
3 & 1 & 3 & 5 & 8 & 17 \\
& & & $(1)$ & $(6)$ & \\
\hline 漫潤様式 & & & & & \\
$\alpha$ & 0 & 30 & 7 & 1 & 38 \\
$\beta$ & 1 & 14 & 24 & 6 & 45 \\
$\gamma$ & 0 & 1 & 3 & 5 & 9 \\
\hline 計 & 1 & 45 & 34 & 12 & 92 \\
\hline
\end{tabular}

細胞異型度, 漫潤様式は, 組織中に認められた最も悪性度の 高いものを表示した。（）内はG3を主とした（G3，G3> G2）症例数を示す

のと浸潤様式 $\gamma$ が多かった（それぞれ $\mathrm{p}<0.01, \mathrm{p}<$ 0.05)。なお, T3で異型度 G3を主とした 1 例は術後 3 カ月で癌死し, T2 3で浸潤様式 $\gamma$ の 4 例のうち 1 例 は術後 3 力月で癌死し, 他の 3 例は術後 7 力月未満で 癌有り生存中であった。肉腫様構築が見られた 9 例中 8 例が $\mathrm{T} 4$ 症例であり, 他の 1 例 (T2) は術後 9 カ月で 癌死した。細胞異型度 G3を主とするもの, 浸潤様式 $\gamma$, 肉腫様構築のいずれかを有する症例は 1 年生存率が $0 \%$ あった。.

図 1 にT4症例の腎摘出術後の performans status を示す。術前に保存的方法で制御できない症状があっ たのは 1 例 (症例10)のみであった。術後 performans status 2 以下の状態を得ることができた症例は退院で きた 6 例であった。術後 1 カ月以内に死亡した 2 例を 除く 10 例の $5 ち 5$ 例は術後 1.5 力月以内に退院できな
因 $1 \quad \mathrm{~T} 4$ 症例の performans status の経過

\begin{tabular}{|c|c|c|c|c|}
\hline 症例 & 術前 & 術後p.s. および経過期間 & & 術後 \\
\hline & & 1.53 & 12 (フ月） & \\
\hline 1 & 3 & 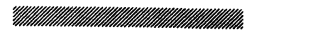 & & $(-)$ \\
\hline 2 & 1 & Yum Im: & & 放射線 \\
\hline 3 & 1 & 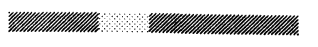 & & o. C \\
\hline 4 & 1 & YWIII: & & 0,1 \\
\hline 5 & 1 & $y=$ & & $(-)$ \\
\hline 6 & 1 & 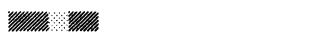 & & I \\
\hline 7 & 2 & 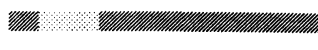 & & $\mathrm{O}, \mathrm{C}$ \\
\hline 8 & 1 & 参 & & $(-)$ \\
\hline 9 & 1 & 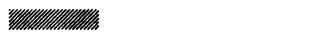 & & 0 \\
\hline 10 & 4 & 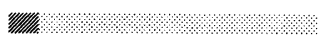 & $/ /$ : : vinumd f / & o \\
\hline 11 & 1 & 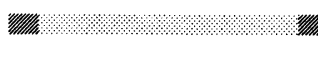 & & 0 \\
\hline 12 & 0 & Y. & & I, C \\
\hline
\end{tabular}

P. S. = performans status

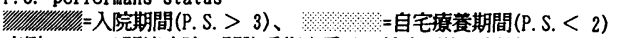
症例 1、7 は関連病院で開腹手術を受け、摘出不能と判断された症例。 $\mathrm{O}=0 \mathrm{~K}-432 、 \mathrm{I}=$ interferon、 $\mathrm{C}=\mathrm{MMC}, 5-\mathrm{FU}$

症例 2 は術前補助㞠法 (O+C + progesterone) 施行。

症例 7 は腎摘出術前に腎動脈塞栓術を受けた。

かったが，その理由は膵液瘦あるいは高 $\mathrm{Ca}$ 血症の治 療（症例 1, 3), 放射線療法（症例 2 ), 免疫化学療 法（症例12）のためであった。残る 1 例（症例 9 ）は 術後早期の局所再発のため退院できずに死亡した. 1 例（症例12）は術後 5 力月目に脳転移に対する摘出術 を受けたが，脳転移による症状が改善しないまま癌死 した。

T4症例のらち術後自宅療養 (Performans status 2

表 6 細胞異型度, 浸潤様式別の生存率

\begin{tabular}{|c|c|c|c|c|c|c|}
\hline & 症例数 & 生存月数中央値 & 1 年生存率 (\%) & 3 年生存率 (\%) & \multicolumn{2}{|c|}{5 年生存率 (\%) } \\
\hline 異型度 & & & & & & \\
\hline 1 & 16 & 34 & 93 & 93 & 93 & \\
\hline 2 & 54 & 22 & 87 & 67 & 38 & \\
\hline 3 & $\begin{array}{c}16 \\
(7)\end{array}$ & $\begin{array}{l}7.5 \\
(3)\end{array}$ & $\begin{array}{c}32 \\
(0)\end{array}$ & 32 & 32 & $\perp^{* *}$ \\
\hline 漫潤様式 & & & & & & \\
\hline$\alpha$ & 36 & 33 & 94 & 8 & 82 & * \\
\hline$\beta$ & 41 & 19 & 77 & 60 & 29 & \\
\hline$\gamma$ & 9 & 4 & 0 & & & \\
\hline
\end{tabular}

細胞異型度, 漫潤様式は, 組織中に認められた最も悪性度の高いものを表示した

（ ）内は G3を主とした（G3，G3>G2）症例を示す

* : p $<0.05^{* *}: \mathrm{p}<0.001$ 
以下）できた期間が 2 カ月を越えた症例は 3 例であっ た。このらち 1 例（症例 4 ）は自宅療養期間中に月経 の再現が認められた。他の 1 例（症例10）は腰筋に浸 潤した腫瘍を鈍的に剥離摘出したが，明らかな遠隔転 移や局所再発なしに術後 2 年間は社会活動ができた。 残る 1 例（症例11）はインターフェロンで肺転移が縮 小したが，術後 9 カ月目に肺転移の増悪と局所再発が 現れた。

\section{考 察}

腎摘出術を行い病期を確定し得た95例の腎細胞癌の らち転㷌の判明した 88 例の 5 年生存率は全体で $54 \%$,

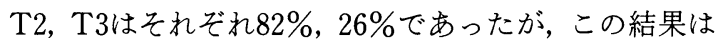
諸家の報告とほとんど同じである2 ${ }^{2) 51}$. 腎摘出術を 行った T4症例（12例）については 1 年生存率が $8 \%$, 3 年生存率が $0 \%$ と著しく不良で，腎摘出術を受けな かった T4症例の生存率の報告と比較すると腎摘出術 による延命効果はなかったと言える67).

従来，T4腫瘍は遠隔転移を有する場合と一括して Stage IV として論じられていたため，T4腫瘍に対す る腎摘出術の成績は僅かしかなく，しかもそれぞれ数 例についての成績を述べているに過ぎないが，いずれ も早期に癌死している3) 5). T4症例の生存率が T3に 比べて著しく低いのは，手術時すでに遠隔転移を伴っ ていることが多いことに加えて, 所属リンパ節転移, 特に固定したリンパ節転移が多く，また隣接臟器への 浸潤が可視的浸潤にとどまらないことが原因である。 この状態では，たと光隣接臓器浸潤を合併切除しても 治癒切除は期待できないか，あるいは困難である。そ の結果, 早期の再発や広範転移が多くなるのは当然と 言える. DeKernion は, 術後 6 力月以内の遠隔転移出 現例は予後不良で，局所再発の見られた症例の $86 \%$ は 1 年以内に死亡し, 腫瘍を取残した場合の 6 力月生存 率は $20 \%, 1$ 年生存率は $0 \%$ \%゙ったと述べている が8)，われわれの結果とほぼ一致する。

T3腫瘍では周囲組織を压排するように増大するこ とが殆どであるが, T4腫瘍では周囲組織へ浸透するよ らに増大する。このことは, 組織学的検索で T4腫瘍は 異型度 $\mathrm{G} 3$, 浸潤様式 $\gamma$, 肉腫様構築が多かった事実に 符合する. 癌組織のこのような生物学的特徵が, 隣接 臓器への浸潤を起こし，リンパ節転移や遠隔転移を早 期に生じ, その結果, 治癒切除を困難にしていると考 えられる、すなわち、 T3病期が進展して T4病期になる とするより, T4腫瘍は他の病期の腫瘍と異なる生物学 的特徵を持ち, 進展様式が異なると考学るほらが妥当
である. 勿論，このような癌が $\mathrm{T} 3$ 以下の病期で発見さ れることもあるが，自験例ではそのような症例の成績 が不良であった事実もこの説明を支持している。なお， 腎静脈之大静脈の腫瘍血栓の合併頻度は，T3と T4腫 瘍の間に有意差がみられなかったので，この有無が T3と T4症例の生存率の差に大きな意義があったとは 考光られない。

T4症例に対する腎摘出術の目的は, 1）予後の改善,

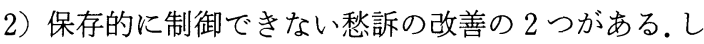
かし，後者に該当する症例は自験例では僅か 1 例で あった，多くの場合は手術で予後を改善できるかが問 題である。予後については単に生存期間についてでは なく，生活の質について論じる必要がある，少なくと も退院して日常生活がある期間できなければ治療の意 義があったとはいえない，その観点から自験例の成績 をみると，手術の意義があったと考兄られるのは12例 中 3 例（25\%）の久である. 若干例でもこのよらな症 例があったことは手術の意義を否定することにならな いが，多くの場合は手術を契機に performans status が低下し，手術合併症で死亡する危険性もあることは 無視できない。

手術の意義があったといえる症例を増やすには手術 適応の判断が大きな比重を占めることになる。多藏器 に遠隔転移がある時は腎摘出術の適応とならないこと は一致した見解である719910). 原発腫湯の組織学的悪性 度が低い場合は，1藏器（特に肺）に遠隔転移があっ ても原発腫瘍を完全に切除できれば，局所再発なしの 長期生存が起こり得るので10111)，その場合は完全に切 除できるか否かが次の問題である。しかし，腹壁への 浸潤や大血管を巻き込んでいる場合を除くと，術前に 判断が困難なので, 試験開腹が必要になる ${ }^{9}$. 開腹して 治癒切除が不可能と判断した場合は，浸潤部の凍結切 片の組織像検索で, 肉腫様構築または異型度 $\mathrm{G} 3$ が認め られれば腎摘出術を断念したほらが現状では適切であ る。これらの組織像がない時は，術後の腎床への放射 線照射の効果に期待して姑息的腎摘出術を行らのも一 つの方法として許されるであろら ${ }^{9)}$. ただし，その意義 については術前の腎動脈塞栓術や免疫化学療法の有効 性とともに今後検討されるべき課題である.

\section{結 語}

腎摘出術を施行した $\mathrm{T} 4$ 腎細胞癌12例について, 臨 床経過と病理組織所見を検討して，次の結果を得た。

T4腎細胞癌は手術時に遠隔転移や固定したリンパ 節転移があることが多く，肉眼的に治癒切除と思われ 
た症例でも術後早期に局所再発や遠隔転移を起こし た。 1 年生存率は $8 \%, 3$ 年生存率は $0 \%$ であった。 病理組織学的には細胞異型度 G3, 浸潤様式 $\gamma$, 肉腫様 構築を持つことが多く, この 3 種の組織学的所見のす べてを主成分とした腫瘍の症例は腎摘出術後 3 カ月以 内に癌死した。腎摘出術後に退院し， 2 力月以上自宅 での日常生活が可能であった症例は 3 例であった。腎 摘出術の意義があったといえる症例を増やすには手術 適応の判断を厳しくし，予後を改善するにはさらに新 しい術前術後の補助療法が必要である。

本論文の要旨は第55回日本泌尿器科学会東部総会で発表 した.

\section{文献}

1) 日本泌尿器科学会, 日本病理学会, 日本医学放射線 学会：腎癌取扱、規約(第 1 版), 金原出版, 東京, 1983.

2) 里見佳昭, 高井修道, 近藤猪一郎, 岩崎孝史, 吉邑 貞夫, 福島修司, 古畑哲彦, 石塚栄一：腎細胞癌の stage 及び grade と予後. 日泌尿会誌, 72, 278-287, 1981.

3）西尾恭規, 西村一男, 飛田収一, 岡田裕作, 竹力秀 雄, 宮川美栄子, 岡田謙一郎, 吉田 修: 腎細胞癌 に対する根治的腎摘除術の治療成績. 第 1 報。腎癌 取扱い規約による進展度分類と予後. 泌尿紀要, 33, $337-343,1987$.
4）勝岡洋治, 河村信夫：腎癌の手術療法一進展度分 類法に基ついた手術療法の評価一. 泌尿器外科, 1, 13-18, 1988.

5）本間之夫，杉本雅幸，箕和田滋，東原英二，阿曾佳 郎：腎細胞癌124例の治療成績。日泌尿会誌, 81, 726-731, 1990.

6）里見佳昭, 高井修道, 福島修司：腎細胞癌摘出不能 例の検討. 臨泌，31，995-999，1977.

7）本間之夫, 阿曽佳郎：抎大手術の意義之限界一腎 細胞癌。癌と化学療法, 16, 1078-1084, 1989.

8) de Kernion, J.B., Ramming, K.P. and Smith, R. B.: The natural history of metastatic renal cell carcinoma: Acomputer analysis. J. Urol., 120, 148-152, 1978.

9) de Kernion, J.B.: Management of renal ademocarcinoma. in Genitourinary Cancer Management. p. 187-217, Lea \& Febiger, Philadelphia, 1987.

10) Maldazys, J.D. and de Kernion, J.B. : Prognostic factors in metastatic renal carcinoma. J. Urol., 136, 376-379, 1986.

11) Neves, R.J., Zincke, H. and Taylor, W.F.: Metastatic renal cell cancer and radical nephrectomy : Identification of prognostic factors and patient survival. J. Urol., 139, 1173-1176, 1988.

（1992年 2 月 4 日受理） 